\title{
The Influence of Plyometric Exercise on the Long Pass Results of Football Players in One Football Club in Magelang Indonesia
}

\author{
Yusuf Sanggantara \\ Master of Sports Science \\ Universitas Negeri Yogyakarta \\ Yogyakarta, Indonesia \\ sanggantara@gmail.com
}

\author{
Suharjana \\ Master of Sports Science \\ Universitas Negeri Yogyakarta \\ Yogyakarta, Indonesia \\ suharjana_pkr@uny.ac.id
}

\begin{abstract}
- this study is aims to determine the effects of exercise applying a plyometric method to determine the extent which the players of Arkansas football clubs of Magelang perform long passes. This study was an experimental study. The research design was "pre experimental." The Population in study was the Arkansas football club players in Magelang aged 17-23 years and the research involved as much as 24 people. The sample was determined by the purposive sampling with data analysis techniques which used statistical tests. The average long pass recorded distance in the pre-test is $41.89 \mathrm{~m}$, while the average long pass recorded distance during the posttest is $44.57 \mathrm{~m}$. The results display a difference between the pretest and posttest mean. The average value of the posttest $>$ pretest mean value when the samples performed long passes. According to these results, it can be interpreted that there is a mean increase in the long pass after being given a plyometric workout of $6.39 \%$. When plyometric exercises are added to the routine training, it significantly increases the long pass distance of Arkansas Football clubs player of Magelang.
\end{abstract}

Keywords—plyometric exercises, long pass, football players

\section{INTRODUCTION}

Throughout time, football undergone rapid development and has improved well and significantly in every part of the world. One of the most visible improvements in football is the use of advanced equipment and infrastructure such as the use CCTV on football pitches during games, and most impressively, the construction of stadiums with retractable roof to protect spectators and players against heat and cold. The success of football is influenced not only by infrastructure, but also other supporting aspects like biology, psychology, and environment. There are various motions in football including running, jumping, bounding, kicking, stomping, and ball catching for goalkeepers. All these activities are required by players to perform their job as football players.

The most dominant move in football is kicking. Once children can kick, they can play football. In football, the purposes of kicking the ball are for passing, shooting towards the goal, clearing and sweeping. The passing technique can be performed either in short or long form of pass to teammates on the field. The long pass is a technical aspect of the pass skill that allows players to pass the ball over long distances to the opponents' area or through penetrating through passes, also, the long pass helps defenders to defend their scoring range and switch the point of attack, and attack the goal from a large distance while the opponent's goalkeeper is not in position (moving some meters outwards the goal) During field observations, it was found that international players (European, American players, etc.) can kick up to $2 / 3$ length of the field with great long passing skill and accuracy. Unfortunately, a lot of Indonesian football players still find it difficult achieve the same feat. For the data collection, the researchers conducted observations and recorded the length of long passes made by the players in a football club in Magelang. From the study, if cemented the fact that Indonesian players have difficulties in making good long passes, this was deduced from the match. During the data collection process, it was found that most participants were able to kick the ball barely to the midfield. It ball reaches about only approximately 41 meters. If players cannot perform this skill, so many difficulties will arise for the team both in training and winning matches. A lot of exercises exist to help improve limb muscular power. They include skipping, barbell, dumbbell, and ball medicine. However, researchers aim to adopt a more effective and efficient method developed in the 2000th century namely the "Plyometric exercise." The Plyometric exercise can help improve football players' performances [1]. The exercise includes front jump (two-foot jump over obstacles). The plyometric exercise is a high intensity training technique that trains athletes' muscles and enables them to exert maximum power in a short time interval [2]. Does plyometric exercise have any influence on long pass?

\section{RESEARCH METHODS}

\section{A. Research Design}

This research adopted a pre-experimental design is not considered as the actual experiment because of other variables that influence the dependent variables. This research was conducted using a One Group Pre-test-Post-test Design. According to measurements, Designs in the One Group Pre-test-Post-test are taken before and after the experiment. Observation conducted prior to the experiment (O1) is named after pre-test while observation following the experiment $(\mathrm{O} 2)$ is named after the post-test [3]. 


\section{B. Research Time and Place}

This research began in February and took 6 weeks to complete. From a physiological and psychological point of view, a 6-week jumping training with maximum intensity is ideal for the coordination of the human central nervous system. Within such duration, the exercise induces human neuromuscular adaptation that contributes to explosiveness without causing hypertension or excessive fatigue [4]. The training was held 3 times a week every Wednesday, Friday, and Sunday. It was held every $3.30 \mathrm{pm}$ in the football field of Salaman Subdistrict Magelang.

\section{Research Subject}

Population of this research was football players of a particular club in Magelang, Indonesia. The population shared similar characteristics such as joined the same football club, relatively similar age between 17 to 23 years old, practiced regularly for over three months, and was willing to participate in this research.

\section{Data Collection Technique, Instrument, and Data} Analysis

a) Data Collection Technique

Data were collected through a set of tests and measurement to collect objective data regarding the results of players' training. Test and measurement in this research recorded the long pass results during pre-test and post-test. Test results are presented in meters.

\section{b) Research Instrument}

To measure the distance of the long passes executed by the players, this research adopted a kicking for distance measurement from Warner Test of Soccer Skills [5]. In this long pass test, players use their strongest leg and kick the ball down the marked field, as far as possible. Each player was given three opportunities in the kicking test. However, only the result with the longest distance would be recorded. The tape meter was used as the measurement device in this research. The distance was measured in meters. Validity and reliability of the test are 0.827 and 0.905 respectively.

\section{c) Data Analysis Technique}

This research tested the difference between two means by comparing the pre-test mean and post-test mean found in the experiment groups. Data in this research were analyzed using statistical techniques. The Mean formula is stated as follow [6].

$$
M=\frac{\Sigma x}{N}
$$

Remarks:

$M \quad$ : total score divided by total individuals

$\Sigma x:$ total scores

$N \quad$ : total individual

If post-test provides greater mean than pre-test does (posttest mean > pre-test mean), then, the plyometric exercise is said to have influence on long pass distance among football players in the football club.

\section{RESUlTS AND DISCUSSION}

TABLE I. DATA SUMMARY OF MEAN COMPARISON

\begin{tabular}{|c|c|c|c|}
\hline Groups & Mean & Mean Difference & Percentage \\
\hline Pre-test & $41.89 \mathrm{~m}$ & $2.68 \mathrm{~m}$ & $\mathbf{6 . 3 9} \%$ \\
\hline Post test & $44.57 \mathrm{~m}$ & 2.3 & \\
\hline
\end{tabular}

The average pre-test and post-test scores are 41.89 and 44.57 respectively. Referring to the summary above, there was an increase of 2.68 or $6.39 \%$ in the average distance of long passes (pre-test and post-test) which resulted from the administered plyometric training. This mean difference test reveals that the $M$ of post-test is greater than the $M$ of pretest ( $\mathrm{M}$ post-test > M pre-test). Therefore, plyometric training is proven to influence the long passes distance.

For pro football players, having great long passing skills is a big advantage to them. This technique enables them to switch the point of attack and make the opponents turn around and retreat. In addition, long passes convey the ball closer to the opponent's goal to makes it easier for other teammates to score goals either by heading or other ball execution techniques. The Plyometric training has been assessed by researchers and proven to increase long pass distance by $6.39 \%$.

The Plyometric exercise is a type of exercise that focuses on lower body movement. Hence, the exercise helps to improve and optimize the power performance lower body. In addition to increasing power, the plyometric exercise focuses on stride length and stride frequency (bounds, horizontal force production) and also improves sprint performance [7]. In the plyometric training program, athletes should be given more resistant weights. Addition of Weight forces muscles to work harder under a high intensity level. To determine the appropriate weight to be incorporated into training program, people should control the height, weight, and length.

This research found that the plyometric exercise also increased the electromyography (EMG) of the biceps femoris in squat moves (absolute power) after four weeks of training (4 sessions per week). Plyometric exercises increase muscle power and causes muscle strain. Tolerating extreme power and strain may cause physiological and biological changes needed by the muscles and other parts of human contraction system [8]. The Plyometric exercise is expected to improve the skills of Arkansas FC players, particularly their long passing skills. Finally, this research has proven that the plyometric exercise increases the long pass distance by $6.39 \%$ among football players. Results of this research provide contribution for future researches and help other researchers make improvement by adding or replacing the treatment for basic passing techniques in football.

\section{CONCLUSION}

Referring to the results of the data analysis, description, results testing, and discussion, it is concluded that plyometric exercise increases the long pass distance by $6.39 \%$ among players of a football club in Magelang. 


\section{REFERENCES}

[1] A. p. N. B. S Maamer. Data concerning the effect of plyometric training on jump performance in soccer players: A meta-analysis. Elsevier, pp. 324-334. 2017.

[2] A. H. Asadi, Effects of high-intensity plyometric training on dynamic balance, agility, vertical jump and sprint performance in young male basketball players. J Sport Health Res, 2012. vol. 4, pp. 34-44

[3] Sugiyono. Metode penelitian kuantitatif kualitatif dan $R \& D$, Bandung: Alfabeta, 2015.

[4] O. J. O. K. C. M. Adams K. "The effects of six weeks of squat, plyometric and squat-plyometric training on power development," $J$ Appl Sports Sci Res, 1992. vol. 6, pp. 36-41

[5] H. M. Barrow. A practical Approach to Measurement in Physical Education. London: Henry Kimton publisher, 1979.

[6] S. Hadi. Statistik Jilid 1. Yogyakarta: Andi Offset. 2000.

[7] R. B. C. J. Saez De Villarreal E. The effects of plyometric training on sprint performance:A meta-analysis," J Strength Cond Res, 2012. vol. 26, p. 575-584

[8] P. A. a. s. S. Rezaimanesh D. The effect of a 4 week plyometric training period on lower body muscle EMG changes in futsal players. Procedia Social and Behavioral Sciences, 2011. vol. 15, pp. 31383142 . 